Original Research Paper

\title{
The Financial Behavior of Jordanian Pharmaceutical Industry
}

\author{
Mamoun Yasien Shakatreh \\ Al-Balqa Applied University/Amman University College, Jordan
}

Article history

Received: 27-07-2018

Revised: $18-08-2018$

Accepted: 10-11-2018

Email:

drmamounshakatreh2018@gmail.com

\begin{abstract}
The study aims to analyze the financial behavior of the Jordanian pharmaceutical industry companies listed in Amman Stock Exchange (ASE) during the period 2005-2015. The study examines the relationship between funding sources and the Return on Equity (ROE) in order to reach conclusions and to make recommendations to enhance the performance of the Jordanian pharmaceutical industry companies. The Generalized Least Square (GLS) test and Hausman test are used to estimate the fixed effects and random effects model. The random effects model proved to be more suitable for testing the impact of the financial behavior on the profitability of the Jordanian pharmaceutical industry as measured by ROE. The study results showed that the financing through equity has a positive and significance effect on the ROE, which explains the fact that the Jordanian pharmaceutical companies mainly depend on equity financing by $67 \%$. The study recommended that the Jordanian pharmaceutical companies should make an effort to finance its capital increase, assets increase and expansion by financing through equity sources.
\end{abstract}

Keywords: Behavioral Finance, Return on Equity, Pharmaceutical Industry, Jordan

\section{Introduction}

Intended financial behavior refers to the level of change in the selection of sources of funding whereby funding decisions are among the most important financial decisions made by management to choose the effective and optimal use of available resources. The sources of funding are divided into equity financing and/or debt financing. The cost of equity financing is the yield return to shareholders while the cost of debt financing is the interest paid to lenders taking into consideration the different methods of debt financing (Kaja and Margus, 2008).

The level of change in the financial structure is commensurate with the size of changes imposed by the variations in financial behavior resulting from the disparity of capital requirements. And that is where companies are facing many challenges which require a corresponding change in their financial behavior. However, the changes in financial behavior could lead to either positive or negative consequences on companies.

The main objective of financial management is to maximize the market value of the company before making any decisions that could potentially affect the company. In general, market value is fundamentally governed by two major decisions; the investment decision and the funding decision. The increase in the market value through investing decisions depends on the increase in cash flow from operating activities while the increase in market value through proper financing decisions results from minimizing the cost of capital or both (Zugheib et al., 2000).

There are several theories about the funding decisions which differentiate between internal funding sources (equity) and external funding sources (borrowing) both short and long term. The theory of Modigliani and Miller (1958; 1963) laid the theoretical foundation of corporate finance, where they demonstrated that the value of a company is not affected by whether it is financed by equity or by debt and that the leverage of the company has no effect on the cost of capital.

The Agency Cost Theory showed that the impact of external financing cost equals the decline in the value of companies in which management is more concerned with maximizing its own special benefits instead of maximizing the company's value. Jensen and Meckling, (1976), Harris and Raviv (1991) and Myers (2001), said that the selection of an appropriate capital structure could 
lead to the elimination of such costs. Grossman and Hart (1982) showed that the increase in debt financing would have a positive impact on the overall cost of capital.

The Trade-Off Theory proposes that the company's goal on leverage is derived from the three forces; the tax, the costs of bankruptcy and the conflict of interests between creditors and shareholders. In general, the Trade-Off Theory assumes that there is an optimal ratio of debt to equity.

According to the Pecking Order Theory, there are three sources of funding for companies; internal funding based on funds generated from the company's retained earnings, debt financing and financing through secondary issues of new shares. The priorities of the funding sources for companies according to this theory come first from internal financing, then debt financing and finally issuing new shares. To that extent, companies generally try to comply with this hierarchy in the selection of the sources of funding where equity financing is the last resort because it opens the door to new shareholders to the companies which could potentially affect the decision-making capability of the company (Brealey and Myers, 2003).

One of the important financial decisions facing the financial management of the companies is a choice between funding resources; relying on short and longterm debt, or rely on equity represented by common shares, reserves and retained earnings. The relationship between capital structure and value of the company has raised the attention of researchers, academics, management and employees (Glen and Pinto, 1994).

The main objective of this paper is to conduct an analysis of changes in the financial behavior of the Jordanian pharmaceutical companies listed in Amman Stock Exchange (ASE) from 2005 to 2015, by testing the relationship between funding resources and Return on Equity (ROE). Therefore, the problem of the study is to answer the following question: Do funding resources affect the rate of return on equity or not? The results and recommendations will hopefully enhance the performance of these companies.

The Return on Equity (ROE) is the return earned by the shareholders and it is considered to be the most comprehensive measure of the effectiveness of management and is one of the most relevant indicators of improving the company's image in the financial markets. ROE increases/decreases investors desire to purchase shares of the company. The study assumes that the company's dependence on equity financing will increase the ROE.

The rest of the paper will be organized as follows: Section tow provides an overview of the development of the Jordanian pharmaceutical industry. The third section reviews the literature study, the fourth section describes the data and methodology used, the fifth section discusses the results while Section six concludes the study and makes recommendations.

\section{Jordanian Pharmaceutical Industry}

Jordanian pharmaceutical industry is one of the most dynamic industries in Jordan. The first pharmaceutical company was established in 1962. In the 1970s, three additional companies were establishment and during the 1980s three more companies entered the market. During the 1990s, the sector witnessed a remarkable development as a result of the establishment of nine companies, This development was a direct result of the flow of capital from the Gulf states because of the Gulf War and also because the Jordanian government enacted several laws and procedures regarding investment to encourage and facilitate investment in Jordan (Amman Chamber of Industry).

The Jordanian Association of Pharmaceutical Manufacturers (JAPM) was established in 1995 as a nonprofit association for the support and development of the Jordanian pharmaceutical industry because it's positive role in advancing the national economy. The Association members included fourteen pharmaceutical factories and seven centers for pharmaceutical research in addition to a single company for the manufacturing of surgical sutures (www.JAPM.com).

During the study period, the Jordanian pharmaceutical industry has grown in terms of investment volume whereby the Jordanian pharmaceutical industry invested around 187 million JOD ( 1 JOD equals to 1.41 USD). It is worth mentioning that the pharmaceutical industry contributes significantly to enhance the balance of trade through Jordanian exports, which amounted to nearly 538 million USD of pharmaceutical products exported in 2015. The Jordanian pharmaceutical industry ranked third in Jordanian exports despite the fact that $40 \%$ of its production depends on concession rights to foreign companies and $60 \%$ depends on the licenses. At the same time, the industry's products accounted for nearly $7.16 \%$ of the total Jordanian exports whereby the products have been exported to more than 60 countries due to their high quality and excellent reputation and competitive pricing (www.JAPM.com). Jordanian pharmaceutical industry contributed to the development of the Jordanian economy as it provided jobs and hard currency to the extent of 4481 jobs and exports accounted for more than $80 \%$ of its products (Taifour, 2011).

\section{Literature Review}

The subject of financing by borrowing or equity attracted the attention of many researchers in the past years and therefore, this study comes as an extension to previous studies. The previous studies have focused on the determinants of capital structure (leverage ratio, 
short-term debt, long-term debt, the company's size, ...etc.) and financial performance indicators (return on assets, return on equity, earnings per share, net income before interest and taxes, net profit margin, ...etc.). The results of those studies varied in so far as some found a positive relationship while others found a negative relationship and some found no relationship.

Table 1 shows the some of the international previous studies:

Ebrati et al. (2013) Found that the capital structure has a positive effect on return on equity and a negative impact on the return on assets and earnings per share from the net profits for 85 companies listed on the Tehran market. Saeed et al. (2013) found that there is a positive relationship between the determinants of capital structure and return on assets and return on equity and earnings per share of Pakistanis' banks.

Awunyo and Badu (2012) concluded that leverage has a negative impact on the return on assets and return on equity in the listed banks in Ghana. The same results were reached by Umar et al. (2012) who studied 100 companies listed in the Karachi Stock Exchange in Pakistan; that the capital structure negatively affects the income before interest, taxes, return on assets, return on earnings per share and net profit margin.

Abbadi and Abu-Rub (2012) measured the impact of capital structure on the performance of the Palestinian financial institutions. They found a positive relationship between the debt ratio and return on equity. A study by Luper and Isaac (2012) results showed that there is a negative relationship between the short-term debt and return on assets and profit margin of industrial companies in Nigeria.

Fozia et al. (2011) studied the impact of capital structure on the performance of the textile companies in Pakistan. They found an inverse relationship between the debt to equity ratio and return on assets and a positive relationship between the growth rate and return on assets.

Prahalathan and Ranjani (2011) examined the capital structure for the performance of companies listed in the Sri Lankan Colombo Stock Exchange. They found no relationship between the ratio of debt and return on assets and return on equity.

El-Sayed (2009) studied the impact of choosing the capital structure of non-financial companies listed on the Egyptian stock market. The study found that the decision to choose between the capital structures has a weak effect and has no influence the companies' performance.

Nikolaos and Maria (2008) looked at similar determining factors of capital structure for large and small projects in Greece and France. They concluded that there are some similarities and some differences in behavior followed by financial managers in both countries. The researcher found that the difference in the strength of the relationship in the choice of capital structure between the two countries and the difference is caused by the company's agents and not the state agents.

Tran and Neelakantan (2006) concluded that choosing the capital structure of small and medium-size enterprises in Vietnam depends not only on the company's properties, but also on the behavior of the administration which has a role in external financing. In addition, the relationship between companies and banks plays an important role in determining the leverage ratio.

Joshua (2005) found that there is a positive and statistically significant relationship with the ratio of total debt to total assets and return on equity for companies listed in Ghana stock exchange.

Table 2 shows the Jordanian previous studies:

Abdel-Jalil (2014) measured the impact of capital structure on its financial performance for the Jordanian industrial companies listed in Amman Stock exchange during the period 2008 - 2012. The study found that there is a negative relationship between debt ratio and the return on investment and return on equity. Also appositive relationship between asset turnover rate and the growth rate on return on investment and return on equity.

Hamdan and Al-Qudah (2013) concluded that the capital structure of the Jordanian banks as measured by total liabilities to assets has a positive effect on return on assets, return on equity and the average earning per share. If the capital structure measured by equity to assets, the results showed that a positive effect on return on assets and a negative effect on both return on equity and the earning per share.

Al-Taani (2013) examined the relationship between capital structure and performance of the Jordanian industrial companies listed in Amman Financial Market. The study did not find a relationship between the debt ratio and return on assets.

Al-Momani and Hassan (2011) aimed to see how the adoption of decisions by financial managers at 54 Jordanian services Companies listed in the Amman Stock Exchange on the special factors of the company and factors specific to the market to choose and determine the ratio of debt for those companies. The study showed that the company's size and structure of assets has had a positive impact on the financial structure, while the return on assets had a negative impact on the financial structure and that the rate of growth has had a positive impact on the financial structure. On the other hand, results proved the lack of impact of the private capital market factors (the tax rate, interest rate, market value of shares of the capital market) in the decisions of financial managers at those companies and that these factors do not explain the changes in the financial structure.

Ramadan and Aloqdeh (2011) studied the capital structure determinants in the Jordanian companies and found a negative relationship between capital structure and company profitability. 
Table 1: Summarizes the previous studies conducted on listed on various global stock markets

\begin{tabular}{|c|c|c|c|}
\hline Researchers & Study year & Study result & Study sample \\
\hline Ebrati et al. & 2013 & $\begin{array}{l}\text { Capital structure has a positive effect on ROE and a } \\
\text { negative impact on the ROA and earnings per share. }\end{array}$ & $\begin{array}{l}85 \text { companies listed in Tehran } \\
\text { stock market. }\end{array}$ \\
\hline Saeed et al. & 2013 & $\begin{array}{l}\text { A positive relationship between the determinants of } \\
\text { capital structure and ROA and ROE and earnings per share. }\end{array}$ & Pakistanis' banks. \\
\hline Awunyo and Badu & 2012 & Financial leverage had a negative effect on ROA and ROE. & $\begin{array}{l}\text { Banks listed in Ghana stock } \\
\text { market. }\end{array}$ \\
\hline Umar et al. & 2012 & $\begin{array}{l}\text { Capital structure negatively affects income before interest } \\
\text { and taxes, ROA, earnings per share and net profit margin. }\end{array}$ & $\begin{array}{l}100 \text { companies listed in the } \\
\text { Karachi Stock Exchange. }\end{array}$ \\
\hline Abbadi and Abu-Rub & 2012 & Positive relationship between the debt ratio and ROE. & Palestinian financial institutions \\
\hline Luper and Isaac & 2012 & $\begin{array}{l}\text { Negative relationship between short-term debt and ROA } \\
\text { and profit margin. }\end{array}$ & Industrial companies in Nigeria \\
\hline Fozia et al. & 2011 & $\begin{array}{l}\text { An inverse relationship between the debt-to-equity ratio } \\
\text { and ROA and the direct relationship between the growth } \\
\text { rate and ROA. }\end{array}$ & Textile factories in Pakistan \\
\hline Prahalathan and Ranjani & 2011 & No relationship between the debt ratio and ROA and ROE. & $\begin{array}{l}\text { Sri Lankan companies registered } \\
\text { in the Colombo Stock Exchange }\end{array}$ \\
\hline El-Sayed & 2009 & $\begin{array}{l}\text { Decision to choose the capital structure has a weak effect } \\
\text { on the company's performance. }\end{array}$ & $\begin{array}{l}\text { Non-financial companies listed } \\
\text { on the Egyptian stock market. }\end{array}$ \\
\hline Nikolaos and Maria & 2008 & $\begin{array}{l}\text { There are some similarities and some differences in behavior } \\
\text { followed by financial managers in Greece and France and } \\
\text { that this difference is caused by the company's agents not } \\
\text { the state agents. }\end{array}$ & $\begin{array}{l}\text { Large and small companies in } \\
\text { Greece and France. }\end{array}$ \\
\hline Tran and Neelakantan & 2006 & $\begin{array}{l}\text { The behavior of the administration's role in external } \\
\text { financing }\end{array}$ & $\begin{array}{l}\text { Small and medium-sized } \\
\text { enterprises in Vietnam }\end{array}$ \\
\hline Joshua & 2005 & $\begin{array}{l}\text { A positive relationship between the ratio of total debt to } \\
\text { total assets and ROE }\end{array}$ & $\begin{array}{l}\text { Companies listed in Ghana stock } \\
\text { exchange. }\end{array}$ \\
\hline
\end{tabular}

Source: prepared by the researcher

Table 2: Summary of the previous studies conducted on companies listed in ASE

\begin{tabular}{|c|c|c|c|}
\hline Researchers & Study year & Study Result & Study Sample \\
\hline Abdel-Jalil & 2014 & $\begin{array}{l}\text { Opposite effect of the debt ratio on return on investment. Opposite } \\
\text { effect of the ratio of debt to equity on the ROE. Positive impact of } \\
\text { asset turnover rate and the growth rate on return on investment and ROE. }\end{array}$ & $\begin{array}{l}\text { Jordanian industrial companies } \\
\text { listed on the ASE during the } \\
\text { period 2008-2012. }\end{array}$ \\
\hline Hamdan and Al-Qudah & 2013 & $\begin{array}{l}\text { Capital structure has a positive effect on ROA, ROE and the average } \\
\text { net profit per share. }\end{array}$ & Jordanian banks listed in ASE. \\
\hline Al-Taani & 2013 & There is no relationship between the debt ratio and ROA. & $\begin{array}{l}\text { Jordanian industrial companies } \\
\text { listed on the ASE. }\end{array}$ \\
\hline Al-Momani and Hassan & 2011 & $\begin{array}{l}\text { The company's size and structure of assets has a positive impact on the } \\
\text { financial structure, but the ROA had a negative impact on the financial } \\
\text { structure, while the rate of growth has had a positive impact on the } \\
\text { financial structure. }\end{array}$ & $\begin{array}{l}54 \text { Jordanian services } \\
\text { companies listed in ASE. }\end{array}$ \\
\hline Ramadan and Aloqdeh & 2011 & A negative relationship between capital structure and profitability. & $\begin{array}{l}\text { Jordanian public shareholding } \\
\text { companies. }\end{array}$ \\
\hline Khrawish and Khraiwesh & 2010 & $\begin{array}{l}\text { A positive relationship between financial leverage and the size of the } \\
\text { company's, long-term and short-term debt. The negative relationship } \\
\text { between financial leverage and profitability. }\end{array}$ & $\begin{array}{l}\text { All Industrial companies listed } \\
\text { in ASE for 2005, total of } 30 \\
\text { companies }\end{array}$ \\
\hline Shalash et al. & 2008 & $\begin{array}{l}\text { Positive relationship between financial structure and the percentage } \\
\text { of the previous debt and the existence of a negative relationship } \\
\text { between financial structure, profitability and liquidity and growth rate. }\end{array}$ & $\begin{array}{l}\text { Jordanian industrial companies } \\
\text { listed in ASE for the perio } \\
\text { d 1997- 2001. }\end{array}$ \\
\hline Zeitun and Tian & 2007 & Capital structure has a negative impact on the financial performance. & 167 Jordanian companies. \\
\hline Tobeishat & 2007 & $\begin{array}{l}\text { Tangible assets, size, the variation in revenues and the average tax rate, } \\
\text { have a positive relationship with the capital structure. But the dividends, } \\
\text { cash flows and profitability are of a negative relationship with the } \\
\text { capital structure. While interest rate and inflation have a positive } \\
\text { relationship with the capital structure. }\end{array}$ & Jordanian services companies. \\
\hline Hnaideh & 2007 & $\begin{array}{l}\text { Retained profits have a positive impact on financial performance, while } \\
\text { financing loans and equity funding have a negative impact on financial } \\
\text { performance. }\end{array}$ & $\begin{array}{l}\text { Jordanian industrial public } \\
\text { shareholding companies. }\end{array}$ \\
\hline
\end{tabular}

Source: prepared by the researcher

Khrawish and Khraiwesh (2010), studied the capital structure of the Jordanian industrial companies listed in the ASE during the period 2001 to 2005. They concluded that there is a statistically significant positive relationship between financial leverage and the size of the company's long-term and short-term debt and that 
there is a negative correlation between leverage ratio and profitability of the company.

Shalash et al. (2008) studied the determinants of the financial structure of Jordanian industrial companies listed in ASE for the period 1997-2001. The study addressed four variables; debt ratio, liquidity and profitability and growth rate. The study concluded that there is a statistically significant and positive relationship between financial structures. Furthermore, the percentage of the previous debt and the existence of a negative and statistically significant relationship between financial structure, profitability and liquidity and growth rate.

While Zeitun and Tian (2007) dealt with the effect of capital structure on the financial performance for 167 Jordanian company. The study concluded that the capital structure has a negative impact on the financial performance of Jordanian companies.

Tobeishat (2007) tested the correlation between capital structure and performance of Jordanian companies in the services sector. The study showed that the assets, size, revenues and the average tax rate have a positive relationship with the capital structure. While the dividend, cash flows and profitability are negatively related with capital structure. Finally, the interest rate and inflation had a positive relationship with the capital structure.

Hnaideh (2007) studied the effect of capital structure on the financial performance of Jordanian industrial companies. The study concluded that funding by retained earnings has a positive impact on the financial performance. However, the funding by loans or issuing new stocks has a negative impact on financial performance.

The previous studies on the Jordanian companies showed that no study were done on the pharmaceutical industry.

\section{Data and Methodology}

The previous studies that have been presented mostly used financial ratio analysis extracted from financial statements. Therefore, this study will follow the same methodology.

The study sample consist of 6 pharmaceutical companies listed in the ASE with a capital of 97 million
JOD out of a total of 14 companies with a capital of 187 million JOD for the period from 2005 to 2015. The study excluded the Jordanian pharmaceutical companies that are not listed in ASE because of the difficulty of data received and the absence of a certified data collection for the purposes of scientific research.

The companies that were selected for the purpose of this study and the study itself were based on the Modigliani and Miller (1958) study. They studied a sample of 42 Energy and Petroleum and 43 electric company public service using regression analysis technique under the assumption that the companies belong to one sector and subjected to the same level of risk. The Fred (1963) criticized the previous study on the grounds that companies within the same sector do not necessarily have equal levels of risk. He gave the example of the energy and petroleum sector, where there are companies operating in nuclear energy and other companies operating on coal-fired power generation and therefore he confined his study to 59 Electricity Company. Furthermore, a study by Alexander (1963) in which he also criticized the study by Modigliani and Miller (1958) whereby he stressed the need to choose the industry accurately, so the companies belong to the same sector are actually subjected to the same level of risk. He conducted his study on 63 companies from the railroad industry where he calculated the variables on the basis of arithmetic averages for the period of the study.

Following Modigliani and Miller (1958) study this study included one industry to understand the behavior of Jordanian pharmaceutical companies listed in ASE, which are subjected to the same level of risk during the period 2005-2015.

Table 3 shows the names of the sample companies and the size of its capital.

This study used time series analysis of cross section data being the most suitable because it takes into account changes over time. It also takes into account the different characteristics of each company in the sample (Bortolotti et al., 2002).

The study is trying to test the relationship between ROE and different sources of funding. Namely, the proportion of equity funding and the proportion of debt financing. The study adopted a model used in many previous studies to test the hypotheses.

Table 3: Sample Companies and the Size of its Capital

\begin{tabular}{lll}
\hline Company & Capital (JD) & Symbol \\
\hline The Jordanian Pharmaceutical Manufacturing PLC. & $40,000,000$ & JPHM \\
Hayat Pharmaceutical Industries Co. P.L.C & $9,500,000$ & HPIC \\
Middle East Pharmaceutical and Chemical Industries Co PLC & $9,869,583$ & MPHA \\
Arab Center for Pharm. and Chemicals PLC & $5,000,000$ & APHC \\
Philadelphia Pharmaceuticals Company PLC & $7,500,000$ & PHIL \\
Dar Al Dawa Development and Investment Company PLC & $25,000,000$ & DADI \\
\hline
\end{tabular}

Source: Prepared by the researcher from ASE, Annual Reports 
The Study Model: Measures the relationship between Return On Equity (ROE) for Jordanian pharmaceutical companies listed in ASE and the proportion of funding of equity (ETA) and the proportion of debt financing (LTA) during the study period:

$$
R O E_{i t}=a_{0}+B_{1} E T A_{i t}+B_{2} L T A_{i t}+e_{i t}
$$

Where:

$R O E_{i t}=$ The rate of return on equity for the company $i$ in year $t$, measured by the net income to equity

$E T A_{i t}=$ The proportion of funding from ownership of the company $i$ in year $t$, measured by the equity to assets

$L T A_{i t}=$ The proportion of debt financing for the company $i$ in year $t$, measured by the liabilities to assets

\section{The Dependent Variable}

Return on Equity (ROE). It is measured by dividing the net profit on the property rights of the company, used to measure the amount of profit earned as a percentage of common shareholders' equity and then the rate of net profit derived by investors to invest their money, as a consequence on their risks in the investment of their money. This ratio indicates the quality of management in the equity funds (Al-Naimi and Al-Tamimi, 2008).

\section{Independent Variables}

Funding ratio of ownership (ETA) measured by equity to total assets. This ratio refers to the percentage contribution of owners' equity in the financing of the company's assets, also refers to the percentage that the shareholders will get from the total assets in the event of liquidation of the company (Al-Sheikh, 2008).

Funding ratio of debt (LTA) measured by liabilities to assets. This ratio refers to the ratio of debt used to finance the company's assets.

The study relies on a number of scientific methods in the analysis, which will use descriptive method of averages, standard deviations and measures of dispersion in order to determine the study data specification. It will also be relying on the analytical method for testing hypotheses. Note that the statistical analysis and hypothesis testing will be using a statistical program (E-views).

The study will estimate the model according to the following steps:

1- Describe the data statistically by finding averages and standard deviation

2- The relationship between variables using one of the following methods Analysis

- Ordinary Least Square (OLS): the study used simple linear regression between the dependent and independent variables
- $\quad$ Fixed Effects Model (FE) is a statistical model that represents the observed quantities in terms of explanatory variables that are treated as if the quantities were non-random. In panel data analysis, the term fixed effects estimator (also known as the within estimator) is used to refer to an estimator for the coefficients in the regression model. Fixed Effects assume that time independent effects for each company that are possibly correlated with the regresses (Gardiner et al., 2009)

- Random Effects Model (RE) is a kind of hierarchical linear model. It assumes that the data being analyzed are drawn from a hierarchy of different populations whose differences relate to that hierarchy. In econometrics, random effects models are used in the analysis of hierarchical or panel data when one assumes no fixed effects. The random effects model is a special case of the fixed effects model (Gardiner et al., 2009)

3- Hausman (1978) test is a statistical hypothesis test in econometrics. It helps one evaluate if a statistical model corresponds to the data

4- T-test is a statistical hypothesis test in which the test statistic follows a Student's t-distribution under the null hypothesis. It can be used to determine if two sets of data are significantly different from each other. A t-test is most commonly applied when the test statistic would follow a normal distribution if the value of a scaling term in the test statistic were known (Gujarati, 2009)

\section{Empirical Results}

\section{Descriptive Statistics for Dependent and Independent Variables Results}

Table 4 shows a summary of the descriptive statistics of the dependent and independent variables, where the mean and median show the highest value and the lowest value and standard deviation for each independent and dependent variables.

The mean and median of (ROE) are (-7.09) and (3.29) respectively. This percentage reflects that the Jordanian pharmaceutical companies do not achieve a good profit for its shareholders. However, the percentage of financing from equity was average (66.87) and the medium was (64.91). Also the average funding ratio of debt (33.12) and the medium was (35.09). This indicates that almost $67 \%$ financed from equity source of the funds invested in the Jordanian pharmaceutical companies (assets) and 33\% financed from both short and long term debt.

Table 5, shows the relationship between the independent and dependent variables on the one hand and between the independent variables with each other on the other hand in order to make sure that there is no 
strong correlation with each other which refers to auto correlation between the two variables and multiple among more than two variables. This will negatively affect the sincerity of the regression results. The table suggests that the relationship between the independent variables, Funding ownership Ratio (ETA) and the proportion of debt financing (LTA) is strong in terms of (0.5378) which suggests a strong correlation between the percentage of financing property and the proportion of debt financing, which might have to do with the correlation between independent variables with each others' impact on the appropriate form, so it will address the problem of the correlation between the independent variables in the model estimation.

\section{The Regression Analysis Results}

The study have been estimating the fixed effects model, random effects model, Hausman test and Generalized Least Square (GLS). The results of the assessment pointed to the existence of two problems: The problem of auto correlation or serial correlation between the residuals and Multicolinearity problem, which indicates that the relationship between two independent variables is stronger than the relationship between one of these two variables and the dependent variable and this confirms the results of the correlation matrix between the variables in the Table 5. To avoid these problems, the study made adjustments on the sample in order to resolve the problem of autocorrelation between residuals problem where it was taking into account the heterogeneity and autocorrelation limit error (Greene, 2012) and deleted the second independent variable which is the debt financing ratio (LTA) which is strongly related to the proportion of equity financing (ETA).

The Hausman test indicated that the random effects model is appropriate to test the impact of the financial behavior on the profitability of the Jordanian pharmaceutical industry as measured by ROE where the Chi Square is $13.6 \%$, which is greater than $5 \%$ (probability of Chi Square less than 5\%).

The results from Table 6 indicate that the ETA coefficient has a positive effect and of statistical significance on the ROE where the value was1.86. This is due to an increase in funding from equity especially from profits and retained earnings, which increases the shareholders profits. Every Jordanian Dinar of the company's assets that has been financed by equity achieves a return of $1.86 \mathrm{JOD}$ to the shareholders. This is an indication that the Jordanian pharmaceutical industry companies rely on equity financing in the amount of nearly $67 \%$ and on debt financing in the remaining $33 \%$. This explains the behavior of those companies in terms of financing. This result is consistent with the results of the study (Hnaideh, 2007; Ebrati et al., 2013; Saeed et al., 2013; Joshua, 2005).

Table 4: Dispersion of the variables

\begin{tabular}{lrrr}
\hline & \multicolumn{1}{c}{ ROE } & \multicolumn{1}{c}{ ETA } & \multicolumn{1}{c}{ LTA } \\
\hline Mean & -7.092970 & 66.873950 & 33.12605 \\
Median & 3.289000 & 64.912500 & 35.08750 \\
Maximum & 51.006000 & 95.324000 & 95.17300 \\
Minimum & -412.373000 & 4.827000 & 4.67600 \\
Std. Dev. & 53.947800 & 20.538080 & 20.53808 \\
Skewness & -6.574504 & -0.685160 & 0.68516 \\
Kurtosis & 49.824210 & 2.992509 & 2.992509 \\
Jarque-Bera & 6504.859000 & 5.164044 & 5.164044 \\
Probability & 0.000000 & 0.075621 & 0.075621 \\
Sum & -468.136000 & 4413.681000 & 2186.31900 \\
Sum Sq. Dev. & 189173.700000 & 27417.820000 & 27417.82000 \\
Observations & 66.000000 & 66.000000 & 66.00000 \\
\hline Source: prepared by the researcher & &
\end{tabular}

Source: prepared by the researcher

Table 5: Correlation matrix between the variables of the study

\begin{tabular}{llll}
\hline & ROE & ETA & LTA \\
\hline ROE & 1.0000000 & 0.537872 & -0.53787 \\
ETA & 0.5378717 & 1.000000 & -1.000000 \\
LTA & -0.5378717 & -1.000000 & 1.000000 \\
\hline
\end{tabular}

Source: Prepared by the researcher

Table 6: The study results

\begin{tabular}{llll}
\hline Variable & Coefficient & Std. Error & t-Statistic \\
\hline C & -131.772 & 27.74759 & -4.748952 \\
ETA & 1.864388 & 0.406445 & 4.587062 \\
R-squared 0.358908 & & Mean dependent var-7.09297 & \\
Adjusted R-squared 0.293712 & & S.D. dependent var53.9478 & \\
S.E. of regression 45.33823 & Akaike info criterion10.56618 & \\
Sum squared resid 121277.7 & Schwarz criterion10.79842 & \\
Log likelihood-341.684 & Hannan-Quinn criter.10.65795 & \\
F-statistic 5.50508 & Durbin-Watson stat1.119261 & \\
Prob(F-statistic)0.00014 & & \\
Cross-section random effects test equation: & & \\
Dependent Variable: ROE & & \\
Sample: $2005-2015$ & & \\
Periods included: 11 & & & \\
Cross-sections included: 6 & & & \\
Total panel (balanced) observations: 66 & & & \\
\hline
\end{tabular}

Source: prepared by the researcher 
The results of the analysis also indicate that the percentage of equity financing accounted for $35.9 \%$ of the changes in the ROE, which means that the funding ratio of ownership explains the results. The results of the analysis also indicate the appropriateness of the model and the independent variables used because $F$ calculated value was 5.5 .

The results of model estimation after solving the problem of the link between the residuals and the problem of the relationship between the variables shows in Table 6.

\section{Conclusion and Recommendation}

The choice of sources of funding decision is a crucial decision for the management of any company. The funding decision impacts the management gool to maximize the companies value by incrasing the value of its market shares. The study found that the percentage of equity financing has a positive and significant effect on the Returne On Equity (ROE), which means that the increased ownership percentage in the financing structure of the Jordanian pharmaceutical companies will increase the ROE achieved by those companies to its shareholders.

Based on the study results, the study recommends that management of the Jordanian pharmaceutical companies, to increase its capital and its financing assets through equity financing methods to be in line with the study results.

\section{Ethics}

This article is original and contains unpublished material. The corresponding author confirms that all of the other authors have read and approved the manuscript and there are no ethical issues involved.

\section{References}

Abbadi, S. and N. Abu-Rub, 2012. The effect of capital structure on the performance of Palestinian financial institutions. Brit. J. Econ. Finance Manage. Sci., 3: 92-101.

Abdel-Jalil, T., 2014. The impact of capital structure on the performance of the Jordanian publicly-held industrial companies. Jordanian J. Bus., 10: 390-403.

Al-Sheikh, M., 2008. Financial Analysis. 1st Edn., Ramallah-Palestine.

Alexander, B., 1963. The effect of capital structure on the cost of capital. Prentice-Hall, Inc.

Al-Momani, G. and A. Hassan, 2011. The determinants of financial structure choice an analytical study over service sector firms listed in Amman's stock exchange. Derasat, 38: 367-379.
Al-Naimi, A. and A. Al-Tamimi, 2008. Analysis and Financial Planning: Contemporary Trends. 1st Edn., Dar Alyazordi, Amman-Jordan.

AL-Taani, K., 2013. The relationship between capital structure and firm's performance. J. Finance Account., 1: 41-45. DOI: $10.11648 /$ j.jfa.20130103.11

Amman Chamber of Industry, "Annual Report”, 2005 2015.

Amman Stock Exchange (ASE), “Annual Report”, 20052015.

Awunyo, D. and J. Badu, 2012. Capital structure and performance of listed banks in Ghana. Global J. Human Soc. Sci., 12: 57-62.

Bortolotti, B.J. Souza, M. Fantini and W.L. Megginson, 2002. Privatization and the sources of performance improvement in the global telecommunications industry. Telecommun. Policy, 26: 243-268. DOI: 10.1016/S0308-5961(02)00013-7

Brealey, R.A. and S.C. Myers, 2003. Principles of Corporate Finance. 7th Edn., McGraw Hill, Boston, ISBN-10: 0072552743, pp: 1071.

Ebrati, M.R., F. Emadi, R.S. Balasang and Safari, 2013. The impact of capital structure on firm performance: Evidence from Tehran stock exchange. Aus. J. Basic Applied Sci., 7: 1-8.

El-Sayed, E.I., 2009. The impact of capital-structure choice on firm performance: Empirical evidence from Egypt. J. Risk Finance, 10: 477-487. DOI: $10.1108 / 15265940911001385$

Fozia, M., B. Niaz and A. Ghulam, 2011. Capital structure and firm performance: A case of textile sector of Pakistan. Asian J. Bus. Manage. Sci., 1: 9-15.

Fred, W.J., 1963. A test of cost of capital propositions. Southern Economic J., 30: 105-112. DOI: $10.2307 / 1055958$

Gardiner, J.C., Z. Luo and L.A. Roman, 2009. Fixed effects, random effects and GEE: What are the differences? Stat. Med., 28: 221-239.

DOI: $10.1002 / \mathrm{sim} .3478$

Glen, J. and B. Pinto, 1994. Debt or equity? How firms in developing countries choose, international financial corporation. The World Bank, Washington, D.C. USA.

Greene, W., 2012. Econometric Analysis. 7th Edn., Pearson.

Grossman, S. and O. Hart, 1982. Corporate Financial Structure and Managerial Incentives. In: The Economics of Information and Uncertainty, Mcmall, J. (Ed.), University of Chicago, Chicago, pp: $107-140$.

Gujarati, D.N., 2009. Basic Econometrics. 4th Edn., Tata McGraw-Hill Education, New Delhi, ISBN-10: 0071333452, pp: 886. 
Hamdan, N. and A. Al-Qudah, 2013. The effect of capital structure on the performance of Jordanian banks listed on Amman stock-exchange: An analytical study. Al-Manarah J., 19: 159-186.

Harris, M. and A. Raviv, 1991. The theory of capital structure. J. Finance, 46: 297-355. DOI: $10.1111 / \mathrm{j} .1540-6261.1991 . t b 03753 . x$

Hausman, J.A., 1978. Specification tests in econometrics. Econometrica, 46: 1251-1271. DOI: $10.2307 / 1913827$

Hnaideh, M., 2007. The impact of capital structure on its financial performance. PhD Thesis, Amman Arab University.

Jensen, M. and W. Meckling, 1976. Theory of the firm: Managerial behavior, agency costs and capital structure. J. Financial Econom., 3: 305-360. DOI: $10.1016 / 0304-405 X(76) 90026-X$

Joshua, A., 2005. The effect of capital structure on profitability: Empirical analysis of listed firms in Ghana. J. Risk Finance, 6: 438-445.

DOI: $10.1108 / 15265940510633505$

Kaja, L. and L. Margus, 2008. The main changes in financial behaviour of Estonian firms in transition economy. Int. Bus. Econom. Res. J., 7: 1-10.

Khrawish, H. and A. Khraiwesh, 2010. The determinants of the capital structure: Evidence from Jordanian industrial companies. JKAU: Econ. Adm., 24: 173-196. DOI: 10.4197/Eco.24-1.5

Luper, I. and M.K. Isaac, 2012. Capital structure and firm performance: Evidence from manufacturing companies in Nigeria. Int. J. Bus. Manage., 2: 1-7.

Modigliani, F. and M. Miller, 1958. The cost of capital, corporate finance and the theory of investment. Am. Economic Rev., 48: 261-297.

Modigliani, F. and M. Miller, 1963. Corporate income taxes and the cost of capital: A correction. Am. Economic Rev., 53: 433-443.

Myers, S., 2001. Capital structure. J. Econom. Perspective, 15: 81-102. DOI: 10.1257/jep.15.2.81

Nikolaos, D. and P. Maria, 2008. Do country or firm factors explain capital structure? Evidence from SMEs in France and Greece. Applied Finan. Econom., 18: 87-97.
Prahalathan, B. and R.P.C. Ranjani, 2011. The impact of capital structure-choice on firm performance: Empirical investigation of listed companies in Colombo stock exchange, Sri Lanka. Int. J. Res. Commerce Manage., 2: 12-16.

Ramadan, E. and S. Aloqdeh, 2011. The determinants of capital structure-evidence from Jordan. Jordan J. Bus. Admin., 7: 228-245.

Saeed, M., A. Gull and M. Rasheed, 2013. Impact of capital structure on banking performance (a case study of Pakistan). Interdisciplinary J. Contemporary Res. Bus., 4: 393-403.

Shalash, S., A. AL-Bakom and A. AL-Awon, 2008. Determinants of the financial structure of the business: An empirical case in Jordanian public shareholding companies listed in Amman stock exchange for the period (1997-2001). Al-Manarah J., 14: 45-81.

Taifour, M., 2011. The relationship between the capital expenditure and financial operational performance in Jordanian pharmaceutical manufacturing corporations. MSc Thesis, Middle East University, Amman, Jordan.

The Jordanian Association Of Pharmaceutical Manufacturers. www.JAPM.com

Tobeishat, F., 2007. The capital structure on corporate performance and growth opportunities, empirical study on Jordan. PhD Thesis, Arab Academy for Banking and Financial Sciences, Amman, Jordan.

Tran, K. and R. Neelakantan, 2006. Capital structure in small and medium-sized enterprises: The case of Vietnam. Asean Economic Bull., 23: 192-211. DOI: 10.1355/AE23-2D

Umar, M., Z. Tanveer, S. Aslam and M. Sajid, 2012. Impact of capital structure on firms' financial performance: Evidence from Pakistan. Res. J. Finance Account., 3: 1-13.

Zeitun, R. and G. Tian, 2007. Capital structure and corporate performance: Evidence from Jordan. Australasian Account. Bus. Finance J., 1: 40-61.

Zugheib, M., G. Naima and Z. Qamary, 2000. A study of financial behavior in the Algerian industrial enterprises: A case study. 